\title{
THE AETIOLOGY OF SARCOIDOSIS
}

\author{
By Lours E. Siltzbach, M.I). \\ Department of Medicine, The Mount Sinai Hospital, New York, N.Y.
}

Although it is more than 80 years since Hutchinson (I875) described his first case of cutaneous sarcoidosis, its aetiology has not been satisfactorily explained and is still a matter of lively debate. It is not clear whether sarcoidosis represents an infectious granuloma, a chemical intoxication, a disordered lipid metabolism or an exceptional hyperimmune tissue response to one or more exogenous or endogenous stimuli. Sarcoidosis has not yet been transmitted to an experimental animal. Hence the approach to the question of aetiology must remain an indirect one.

There are two major aetiological concepts of sarcoidosis: that it is not tuberculosis, and that it is. The case for each view has been argued with vigour for many years, but the two sets of ideas have remained virtually irreconcilable.

The first school holds that sarcoidosis is most likely an independent disease entity with an undisclosed aetiology and is of unknown pathogenesis. It is recognized that many other epithelioid-cell granulomas of known aetiology simulate sarcoidosis quite closely, but, this school maintains, these disorders deviate from sarcoidosis in important respects and can usually be distinguished from it. The occasional occurrence of caseous tuberculosis in sarcoidosis is looked upon as a complication similar to the superimposed tuberculosis met with in cases of silicosis, leprosy and bronchogenic carcinoma. The hypothesis that sarcoidosis is an independent non-tuberculous disease is most popular in some Scandinavian countries and in the United States.

The second school, which is equally large, puts forward the concept that sarcoidosis may be not one disease, but a group of granulomatous diseases of known and distinct aetiology: tuberculosis, histoplasmosis, tuberculoid leprosy and beryllium poisoning, among others. Therefore, use of such terms as ' tuberculous sarcoidosis,' ' histoplasma sarcoidosis ' and 'beryllium sarcoidosis' is recommended (Scadding, I956). Patients with idiopathic sarcoidosis, it is stated, differ from the others mainly in that the tissues contain no identifiable causative agent. It is believed that most cases of idiopathic sarcoidosis belong to the tuberculous group and the absence of tubercle bacilli is ascribed to the unusual phase of tuberculosis through which the patient with sarcoidosis is passing. 'The second school has most of its adherents in Great Britain and some Continental countries.

Objections have been raised by advocates of the second concept to the logic of defining sarcoidosis as a disease of unknown aetiology. For, it is reasoned, if patients with idiopathic sarcoidosis are removed from the category of sarcoidosis whenever a causative agent is found in the tissues, one must always be left with a residual group which, by definition, cannot have a demonstrable cause. Consequently, the aetiology of sarcoidosis can never really be discovered. The persistent failure to implicate an all-inclusive specific agent in idiopathic sarcoidosis up to now adds weight to the objection.

Yet the question arises whether it is necessarily a breach of logic to suppose that the cause of sarcoidosis is still unknown and may be found in the future. A somewhat analogous situation existed a little more than ro years ago when it was found that a surprisingly high proportion of young adults and children residing in the Mississippi basin had asymptomatic pulmonary calcification. The lesions were in most instances associated with a negative tuberculin test. It was at first supposed that these young persons had rapidly run the gamut of tuberculous infection, caseation and healing by calcification. It was thought that healing had been so complete the patients no longer responded to tuberculin. This explanation was soon discarded, since it did not accord with previous experience. Hence tuberculin-negative pulmonary calcification was, for a short time, considered an idiopathic condition. As is well known, the close relationship with the fungus histoplasma capsulatum was later established. It was then clear that most pulmonary calcification among young persons in the area was the result of benign histoplasmosis. Idiopathic pulmonary calcification shrank to insignificant proportions.

If this analogy is valid, it remains logically possible that there may be a single agent underlying idiopathic sarcoidosis which, when un- 
covered, might also result in the removal of most cases of sarcoidosis from the idiopathic category.

\section{Immunological Aspects Related to Aetiology}

Before examining the specific arguments favouring the tuberculous and the non-tuberculous aetiology respectively, a brief discussion of some of the theoretical tenets underlying each concept may be helpful. These concern mainly the anomalous insensitivity of patients with sarcoidosis to various skin antigens, particularly tuberculin. This peculiar behaviour has been cited in support of each hypothesis.

For more than thirty years sarcoidosis has been widely viewed as an exceptional form of tuberculosis. It has been postulated that in sarcoidosis the patient has an enhanced capacity to destroy tubercle bacilli in the tissues, and this accounts for the inability to identify tubercle bacilli in the sarcoid follicles. The rapid destruction of tubercle bacilli releases into the blood-stream large quantities of tuberculo-protein which, it is assumed, evokes an immunologic response in the form of tuberculin-neutralizing substances. These antibodies inhibit the cutaneous reaction to tuberculin, which accounts for the fact that more than twothirds of patients with sarcoidosis are insensitive. A hyperimmune state is present in sarcoidosis, it is presumed, and it has been termed 'positive anergy.' Not all advocates of the tuberculous aetiology of sarcoidosis adhere to this concept, however.

The proponents of the concept of positive anergy have not been able to marshal convincing support for the hypothesis and, as a result, the theory has been falling somewhat into disfavour. A recent study has shown, for example, that tuberculin-neutralizing substances do not occur any more often or in greater amounts in the serum of patients with sarcoidosis than they do in normal control subjects (Magnussen, 1956). Moreover, if one may draw a parallel between BCG organisms and human tubercle bacilli, the enhanced capacity for destroying acid-fast bacilli in sarcoidosis cannot be demonstrated. BCG organisms remain alive at vaccination sites for just as long a period in patients with sarcoidosis as in normal susceptible control subjects (Rostenberg, 1953; Forgacs et al., 1957).

It is becoming clear, too, that negative tuberculin tests in patients with sarcoidosis need not imply the absence of previous tuberculous infection. There are numerous examples of patients with sarcoidosis who are known to have been tuberculinpositive before the onset of sarcoidosis. The sensitivity wanes and disappears when the clinical symptoms of sarcoidosis appear and when the sar- coidosis subsides the sensitivity to tuberculin may return (Nitter, I953).

Of perhaps greater moment from the aetiologic standpoint is the well-confirmed finding that low cutaneous sensitivity to tuberculin in sarcoidosis extends to other unrelated cutaneous antigens of the delayed tuberculin type. Patients with sarcoidosis have been found to be equally unresponsive to trichophytin, oidiomycin, histoplasmin, mumps virus and pertussis agglutinogen (Friou, 1952; Sones and Israel, 1954; Quinn et al., 1955).

Furthermore, unresponsiveness to intracutaneous tuberculin and the other antigens is present among patients with Hodgkin's disease (Schier et al., 1956). This suggests that widespread involvement of the reticulo-endothelial system common to both diseases may be one of the factors responsible for the feeble cutaneous responses. Neither complement fixation nor agglutinin antibody formation is depressed in sarcoidosis (Sones and Israel, 1954; Quinn et al., 1955; Sands et al., 1955).

Other data throw light on the mechanism of tuberculin insensitivity in sarcoidosis. When a paraffin oil suspension of tuberculin (depottuberculin) is substituted for aqueous tuberculin, patients with sarcoidosis yield almost as high a frequency of positive cutaneous responses as do control subjects of the normal population (Seeberg, 195 I; James and Pepys, 1956). This finding suggests that patients with sarcoidosis have difficulty in fixing aqueous tuberculin at the injection site long enough to elicit a reaction. There may, in addition, be a defect in the capacity to produce and transport the proper quantity and quality of white cells which are thought to conduct to the skin the antibodies responsible for the delayed tuberculin-type reaction (Pepys, I955).

All these findings lend meagre support to the hypothesis that sarcoidosis is tuberculosis in a phase of positive anergy.

\section{Arguments Favouring Tuberculosis Aetiology}

Much evidence has, however, been brought to light favouring a tuberculosis aetiology of sarcoidosis:

r. Tubercle bacilli are eventually recovered from a substantial proportion of patients with sarcoidosis. At autopsy the incidence of tuberculosis among patients with sarcoidosis has varied between 10 and 25 per cent.

2. Even with careful histopathological studies it is often impossible to distinguish the follicle of sarcoidosis from the tubercle (Zettergren, 1954).

3. Tubercle bacilli are difficult to demonstrate in the epithelioid-cell tubercle of classical tubercu- 
losis unless caseation has occurred. Lepra bacilli are sparse in tuberculoid leprosy.

4. Search for bacterial residues in sarcoid tissue by chromatophoresis and infra-red spectrophotometry has yielded substantial amounts of diaminopimelic acid (DAP) and mycolic acid, two components of tubercle bacilli. This suggests that the tissues of sarcoidosis patients contained live tubercle bacilli in the past and they were responsible for the sarcoid changes (Netherscott and Strawbridge, 1956).

5. There is striking clinical similarity between sarcoidosis and certain indolent, tuberculinnegative bacillary forms of tuberculosis. These intermediate forms may represent a bridge between sarcoidosis and ordinary caseating tuberculosis. The indolent forms of tuberculosis, like sarcoidosis, often prove to be unresponsive to antituberculosis drugs.

6. The roentgen picture of pulmonary sarcoidosis and pulmonary tuberculosis often mimic each other. Hilar node involvement and dissenated lung lesions are common to both.

7. Erythema nodosum occurs at the outset in both conditions. In the United States both sarcoidosis and tuberculosis are more common in the Negro race.

\section{Arguments Favouring Non-tuberculous Aetiology}

Partisans of the non-tuberculous aetiology of sarcoidosis have aimed most of their arguments at disproving its relationship to tuberculosis. One of the most telling points they have offered is the high specificity of the Nickerson-Kveim intracutaneous reaction in sarcoidosis.

The following is a summary of the nontuberculous position:

I. Finding tubercle bacilli in the secretions or tissues of patients with sarcoidosis does not prove that sarcoidosis and tuberculosis are one disease. Tubercle bacilli are isolated even more commonly from patients with silicosis where tuberculosis supervenes.

2. When tuberculosis complicates sarcoidosis the caseous tubercles and the sarcoid follicles, as a rule, lie side by side without histological evidence of transition from one lesion to the other. The sarcoid follicle contains no tubercle bacilli and shows insignificant necrosis. The adjoining caseating tubercle shows necrotic areas often teeming with tubercle bacilli.

3. Unusual patterns of organ involvement are seen in sarcoidosis and differ from those of tuberculosis. Lesions in the uveal tracts, salivary and lacrimal glands, cardiac and skeletal muscle and phalangeal bones are quite commonplace in sarcoidosis, but are rare in tuberculosis. In contrast, pleural involvement in sarcoidosis is seldom seen, but it occurs frequently in tuberculosis.

4. When tuberculosis is associated with sarcoidosis the caseous lesions are found in the organs usually affected by tuberculosis: lungs, lymph nodes, liver, adrenals, etc. At the same time, sarcoid follicles in the salivary glands, eyes and heart do not show caseous transformation, which one might expect in such cases if sarcoidosis were the non-caseating form of tuberculosis.

5. The interpretations given to the finding of DAP and an acid-fast lipid resembling mycolic acid in tissues of patients with sarcoidosis have been questioned. DAP is not only found in tubercle bacilli, but is present in many other microorganisms. Lipids difficult to distinguish from mycolic acid are also present in some normal tissues. Even if these two substances were truly residues of tubercle bacilli once alive in the tissues, their presence would not necessarily indicate a causal connection. Primary tuberculous infection with transient hematogenous dissemination which goes on to complete healing is a common enough phenomenon to account for residues of tubercle bacilli in the tissues. Further work, however, may prove that these findings are valid arguments for the tuberculous aetiology of sarcoidosis.

6. Patients with sarcoidosis do not usually give a strong family or contact history of tuberculosis. Physicians who hold the tuberculous view of $\rightleftharpoons$ sarcoidosis do not treat their patients as a special public health problem.

7. Epidemiologic studies carried out in the United States (Michael et al., 1950; Cummings, 1956) indicate that sarcoidosis is predominantly a rural disease. In this respect it is unlike tuberculosis, which is essentially urban in distribution. The south-eastern states and small pockets in New England and the Mid-West are the principal 'endemic' areas. Michael has pointed to the slightly increased beryllium content of the soil in the south-eastern region, whereas Cummings has been impressed with the prevalence of pine forests in areas where sarcoidosis is most frequently met.

8. Sarcoidosis does not respond with significant regularity to potent anti-tuberculosis drugs. In contrast, the lesions of sarcoidosis frequently respond to steroid therapy. Moreover, patients with sarcoidosis do not experience the explosive ' escapes' from therapy and deterioration which are met with among steroid-treated tuberculous patients when anti-tuberculosis drug therapy is not used. The time table, the clinical course and the prognosis in the two conditions are quite distinct one from the other.

9. The Nickerson-Kveim intracutaneous test has been found to be highly specific for sarcoidosis 
when standardized testing suspensions of known potency are used. In a survey of the world literature, comprising 560 patients with biopsy-confirmed sarcoidosis (Siltzbach, 1957), it was found that the incidence of positive reaction ranged from 65 per cent. to 92 per cent. (Nickerson, 194I; Kveim, 1941; Putkonen, 1943； Nelson, 1949; Danboldt, 1951; Siltzbach and Ehrlich, 1954; Rogers and Haserick, 1954; James and Thomson, 1955; Reid, 1956; Nelson and Schwimmer, 1957). Among 585 patients with diseases other than sarcoidosis only 2 per cent. gave 'false positives' reactions. The 'control' group included 218 patients with tuberculosis and, among them, three patients, or I.5 per cent., gave 'false positives' tests.

Sones and Israel (1955) reported unfavourable experiences with the Nickerson-Kveim reaction. The testing suspensions of these authors yielded only 21 per cent. positive reactions among 28 patients with sarcoidosis, indicating that the suspension these authors used was of somewhat diminished potency. Surprisingly, among 33 patients with tuberculosis they found 'false positives' responses in 42 per cent. of tests. These non-specific responses could be abolished among the tuberculosis patients, however, when the authors filtered their testing suspension. This suggests that some contaminant adhering to the grosser particles of the testing suspension was responsible for the confusing non-specific reaction.

The high specificity of the Nickerson-Kveim intracutaneous test seems to favour an independent non-tuberculous aetiology of sarcoidosis. Still, this evidence for the non-tuberculous aetiology may seem inconclusive to some. Using the analogy to leprosy, the lepromin test, like the NickersonKveim test, has a prolonged period for reaching maturity. It is usually positive in tuberculoid leprosy and negative in lepromatous leprosy. Thus, here are two different responses to a cutaneous test during two different immunological stages of the same disease. The syllogism completes itself when one substitutes sarcoidosis for tuberculoid leprosy, tuberculosis for lepromatous leprosy and the Nickerson-Kveim test for the lepromin test.

Even after carefully assessing these and many other points, each of the two schools remains unconvinced and the battle of aetiology goes on.

Viral, fungal and chemical aetiology of sarcoidosis have each been advocated by a few investigators, but confirmatory evidence of these contentions has not been forthcoming.

Teilen's (1948) theory of allergic hyperglobulinosis and Refvem's (1954) speculation on the relationship of phospholipids to sarcoidosis have aroused considerable interest, but both hypotheses still remain in the realm of investigation.
It may be fitting to close a discussion of the aetiology of sarcoidosis with the statement issued by the Second Conference on Sarcoidosis held at Washington, D.C., on October 21 and 22, 1956, under the auspices of the Division of Medical $C$ Sciences of the National Academy of SciencesNational Research Council. The statement repre- $\stackrel{\vec{D}}{\stackrel{D}{ }}$ sents the present-day consensus on sarcoidosis in the United States:

' Sarcoidosis is a systemic disease, or group of diseases, of undetermined aetiology and pathogenesis. Histologically, it is marked by the presence of epithelioid-cell tubercles, showing little or no necrosis. Varying types of inclusions in giant cells may be present, but are not pathognomonic. A similar histological picture may be found in certain other diseases, especially in infectious granulomas and in beryllium poisoning. Clinically, the disease most frequently involves lymph nodes, lungs, skin, eyes, liver, spleen and phalangeal bones. The course is usually chronic and constitutional symptoms vary markedly. More specific symptoms, when present, relate to the tissues and organs involved.

' The intracutaneous tuberculin test is frequently negative, but a positive test does not controvert the diagnosis. Hyperglobulinaemia and leucopenia are common and hypercalcaemia, hypercalcinuria elevated alkaline phosphatase and eosinophilia are variable, but sometimes significant features of sarcoidosis.

'The diagnosis of sarcoidosis is based upon the above clinical features associated with a compatible histological picture, provided beryllium poisoning and infectious processes of known aetiology can be excluded. Spontaneous clinical recovery, with or without recognizable fibrosis, may result, or sarcoidosis may persist for years with varying functional alteration of the tissues or organs involved, or the disease may follow a progressive course, ending fatally.'

\section{BIBLIOGRAPHY}

$\checkmark$ CUMMINGS, M. M. (1956), Postgrad. Med., 19, 437.

DANBOLT, N. (1951), Acta derm.-venereol. (Stockh.), 31, 184.

FORGACS, P., MCDONALD, C. K., and SKELTON, M. O. (1957), Lancet, i, 188 .

FRIOU, G. J. (1952), Yale F. Biol. Med., 24, 533.

ISRAEL, H. L., and SONES, M. (1955), Ann. intern. Med., 43, 1269.

JAMES, D. G., and PEPYS, J. (1956), Lancet, i, 602.

JAMES, D. G., and THOMSON, A. D. (1955), Quart. F. Med., $24,49$.

KVEIM, A. (1941), Nord. Med., 9, 169.

MAGNUSSON, B. (1956), Acta derm.-venereol. (Stockh.) (Suppl.), $35,1-138$.

MICHAEL, M., COLE, R. M., BEESON, P. B., and OLSON, B. J. (1950), Amer. Rev. Tuberc., 62, 403 .

NELSON, C. T. (1949), Arch. Derm. Syph. (Chicago), 60, 377.

NELSON, C. T., and SCHWIMMER, B. (1957), f. invest. Derm., 28, 55 .

NETHERSCOTT, S. E., and STRAWBRIDGE, W. G. (1956), Lancet, ii, 1132.

Continued on page 267. 
disease are described and illustrated by a hitherto unpublished case report of beryllium disease in a woman whose only contact with beryllium was handling 2 per cent. beryllium copper alloy sheets.

\section{BIBLIOGRAPHY}

AGATE, J. N. (I948), Lancet, ii, 530.

(:HESNER, (. (1950), Ann. intern. Med., 32, 1028.

CUR'TIS, G. H. (1951), Arch. Derm. Syph. (A.M.A. ), 64, 470.

DENARDI, J. M. VA.N, ORDS'TRAND, H. S., CLRTIS, (;. H., and ZIELINSKI, J. (1953), Arch. industr. Hyg., 8, I.

(;ELMAN, I. (1936), .7. industr. Hyg., 18, $37 \mathrm{I}$.

GRIER, R. S., NAISH, P., and FREIMAN, D. (;. (1948), Ibid., 30, 228.

HARDY, H. L., and TABERSHAW, I. R. (19+6), Ibid., 28, 197.

HARDY, H. L. (195I), Lancet, ii, 448 .

I IARDY, H. I. (1956), Amer. Rer. Tuberc., 74, 885.
JAMES, D. GERAINT (1956), personal communication.

JORDAN, W. (I 957), personal communication.

Lancet Annotation (195I), i, I 357.

LEDERER, H., and SAVAGE, J. (1954), Brit. F. industr. Me:l. II, 45 .

LLOYD-DAVIES T. A., and HARDING, H. E. (1950), Ibid 5,671 .

MARRADI FABRONI, S. (1935), Med. d. Lavoro, 26, 297

Progress Report of the Beryllium Case Registry for 1956, Massachusetts General Hospital, Boston I4.

ROGERS, W. N. (1957), Lancet, ii, 267.

SNEDDON, I. B. (I955), Brit. med. F., i, $144^{8}$.

STERNER, J. H., and EISENBUD, M. (1951), Industr. Hlth Monthly, II, 104 .

VAN ORDS'TRAND, H. S., HUGHES, R., and ('ARMODY. M. G. (1943), Cleveland Clin. Quart., ro, ro.

VAN ORDSTRAND, H. S. (1954), Arch. industr. Hyg., 9, 232.

WEBER, H. H., and ENGLEHARDT, W. E. (I 9.33), Z. (jew H.g., IO, 4 I .

WILSON, S. A. (1948), Radiology', 50, 770.

\section{RUTHIN CASTLE, NORTH WALES}

A Clinic for the diagnosis and treatment of Internal Diseases (except Mental or Infectious Diseases). The Clinic is provided with a staff of doctors, technicians and nurses.

The surroundings are beautiful. The climate is mild. There is central heating throughout. The annual rainfall is 30.5 inches, that is less than the average for England.

The Fees are inclusive and vary according to the room occupied.

For particulars apply to THE SECRETARY, Ruthin Castle, North Wales.

Telegrams: Castle, Ruthin

Telephone: Ruthin 66

Bibliography contimued from page 247-Professor Niels Danbolt, M.D. BIBLIOGRAPHY

BESNIER, E. (1898), Ann. Derm. Syph. (Paris), ro, 333.

BOECK, C. (1899), F. cutan. Dis., 17, 543.

BOECK, C. (1916), Arch. Derm. Syph. (Wien), 73, 7I.

BRUINS SLOT, W. J., GOEDBLOED, J., and GOSLINGS, J. (1938), Acta med. scand., 94, 74.

DANBOL'T, N. (1954), 'Sarcoidosis, in Mackenna: Modern 'Trends in Dermatology,' London.

DANLOS (1901), Ann. Derm. Syph. (Paris), 2, 576.

DARIER, J., and ROUSSY, G. (1904), Ibid., 5, 144.

HEERFORDT, C. F. (1909), Arch.f. Ophthalm., 70, 254.

IIUTCHINSON, J. ( 1898 ), 'Archives of Surgery,' Hutchinson, 9, 307 .

JUNGIIN(;, O. (1910), Fortschr. Rimtgenstr., 27, 375
KVEIM, A. (19+1), Nord. Med., 9, 196.

KUTZNITZKY, E., and BITTORF, A. (19)15), M. med. W'schr., 62, 1349 .

I.OFGRE.N, S. (1953), Acta med. scand., 145, 424.

RICKER, W., and CLARK, M. (r949), Amer. \%. Clin. Path., 19, 725

QUINQUAUD (1892), Ann. Derm. Syph. (Paris), 3, Iit2.

RIEDFR, H. (1910), Fortschr. Rüntgenstr., 15, 125.

SALVESEN, H. A. (1935), Acta med. scand., 86, 127.

SlHaumann, J. (1936), Brit. F. Derm., 48, 399.

TenNeson, M. (I892), Ann. Derm. Syph. (Paris), 3, I I 42

WILLIAMS, R. H., and NICKERSON, D. A. (1935), Proc. Sioc. exp. Biol. (N.Y.), 33, 403 .

Bibliography comtimued from page 258-Louis E. Siltzbach, M.D.

NICKERSON, D. A. (19+1), cited by Appel, B., Arch. Derm. Syph. (Chicago), 43, 172 .

NI'TTER, L. (1953), Acta radiol. (Stockh.) (Suppl.), ro5, I-202. PEPYS, J. (1955), Amer. Rev. 'Tuberc., 71, 49.

PUTKONEN, T. (1943), Acta derm.-7enereol. (Stockh.) (Suppl.), 23, $1-194$.

QUINN, E. L., BUNCH, D. C., and YA(iEL, E. M. (1955), F. invest. Derm., 24, 595 .

REFVEM, O. (1954), Acta med. scand. (Suppl.), 294, I-1 46.

REID, J. D. (1956), N.Z. med. F., 55, 275.

ROGERS, F. J., and HASERICK, J. R. (1954), F. invest. Derm., 23, 389 .

ROSTENBERG, A., SZYMANSKI, F. J., BREBIS, G. J., HAEBERLIN, J. B., and SENEAR, F. E., (1953), Arch. Derm. Syph. (Berl.), 67, 306.
SANDS, J. H., PAL.MER, P. P., MAYOCK, R. I., and ('REGER, W. P. (1955), Amer. Ұ. Med., 19, 401 SCADDING, J. (j. (1956), Tubercle, 37, 371 .

SCHIER, W. W., ROTH, A., OSTROFF, G., and SCHRIFT, M. H. (1956), Amer. F. Med., 20, 94.

SEEBERG, G. (1951), Acta derm.-venereol. (Stockh.), 3 I, 426. SILTZBACH, L. E., and EHRLICH, J. C. (1954), Amer. F. Med.
16, 790 .

SILTZBACH, L. E. (1957), Ibid., 22, 84I.

SONES, M., and ISRAEL, H. L. (1954), Ann. intern. Med., 40, 260 SONES, M., ISRAEL, H. I., KRAIN, R., and BEERMAN, H. (1955), $\mathcal{F}$. invest. Derm., 24, 353.

TEILUM, G. (1948), Amer. F. Path., 24, 389.

ZETTERGREN, L. (1954), Acta Śoc. Med. upsalien. (Suppl.), 